\title{
Proton Uptake of Rhodobacter capsulatus Reaction Center Mutants Modified in the Primary Quinone Environment ${ }^{\text {It }}$
}

\author{
Julia Tandori ${ }^{13}$, Jaroslava Miksovska ${ }^{1}$, Marielle Valerio-Lepiniec ${ }^{1}$, Marianne Schiffer ${ }^{2}$, Peter Maróti ${ }^{3}$, \\ Deborah K. Hanson² and Pierre Sebban ${ }^{\star 1}$ \\ ${ }^{1}$ Centre de Génétique Moléculaire, Gif, France; \\ 'Biosciences Division, Argonne National Laboratory, Argonne, IL and \\ ${ }^{3}$ Department of Biophysics, University of Szeged, Szeged, Hungary
}

Received 8 June 2001; accepted 9 November 2001

\section{ABSTRACT}

Flash-induced absorbance spectroscopy was used to analyze the proton uptake and electron transfer properties of photosynthetic reaction centers (RC) of Rhodobacter capsulatus that have been genetically modified near the primary quinone electron acceptor $\left(Q_{A}\right)$. M246Ala and M247Ala, which are symmetry-related to the positions of two acidic groups, L212Glu and L213Asp, in the secondary quinone electron acceptor $\left(Q_{B}\right)$ protein environment, have been mutated to Glu and Asp, respectively. The $\mathbf{p H}$ dependence of the stoichiometry of proton uptake upon formation of the $\mathbf{P}^{+} \mathbf{Q}_{A^{-}}\left(\mathbf{H}^{+} / \mathbf{P}^{+} \mathbf{Q}_{A^{-}}\right)$and $\mathbf{P Q}_{A^{-}}\left(\mathbf{H}^{+} / \mathbf{Q}_{A^{-}}\right)$ (P is the primary electron donor, a noncovalently linked bacteriochlorophyll dimer) states have been measured in the M246Ala $\rightarrow$ Glu and the M247Ala $\rightarrow$ Asp mutant $\mathrm{RC}$, in the M246Ala-M247Ala $\rightarrow$ Glu-Asp double mutant and in the wild type (WT). Our results show that the introduction of an acidic group (Glu or Asp) in the $Q_{A}$ protein region induces notable additional proton uptake over a large $\mathrm{pH}$ region $(\sim 6-9)$, which reflects a delocalized response of the protein to the formation of $\mathbf{Q}_{\mathrm{A}}{ }^{-}$. This may indicate the existence of a widely spread proton reservoir in the cytoplasmic region of the protein. Interestingly, the $\mathrm{pH}$ titration curves of the proton release caused by the formation of $\mathrm{P}^{+}\left(\mathrm{H}^{+} / \mathrm{P}^{+}\right.$: difference between $\mathrm{H}^{+} / \mathbf{P}^{+} \mathbf{Q}_{\mathrm{A}}{ }^{-}$and $\mathrm{H}^{+} / \mathrm{PQ}_{\mathrm{A}}{ }^{-}$curves $)$are nearly superimposable in the WT and the M246Ala $\rightarrow$ Glu mutant RC, but substantial additional proton release is detected between pH 7 and 9 in the M247Ala $\rightarrow$ Asp mutant RC. This effect can be accounted for by an increased proton re-

IIPosted on the website on

*To whom correspondence should be addressed at: Centre de Génétique Moléculaire, Bâtiment 24, Gif 91198, France. Fax: 33-169-82-38-32; e-mail: sebban@cgm.cnrs-gif.fr

$\dagger$ Julia Tandori and Jaroslava Miksovska contributed equally to the work.

Abbreviations: CAPS, 3-(cyclohexylamino)-1-propanesulfonic acid; $\mathrm{H}^{+} / \mathrm{P}^{+} \mathrm{Q}_{\mathrm{A}}{ }^{-}$, proton uptake stoichiometry induced by the $\mathrm{P}^{+} \mathrm{Q}_{\mathrm{A}}{ }^{-}$ state; $\mathrm{H}^{+} / \mathrm{Q}_{\mathrm{A}}{ }^{-}$, proton uptake stoichiometry induced by the $\mathrm{Q}_{\mathrm{A}}{ }^{-}$ state; MES, 2-(N-morpholino)ethanesulfonic acid; $\mathrm{P}$, primary electron donor, a noncovalently linked bacteriochlorophyll dimer; $\mathrm{Q}_{\mathrm{A}}$ and $\mathrm{Q}_{\mathrm{B}}$, primary and secondary quinone, respectively; $\mathrm{RC}$, reaction center; $\mathrm{UQ}_{6}$, ubiquinone-6; WT, wild type.

(C) 2002 American Society for Photobiology 0031-8655/02 $\$ 5.00+0.00$ lease by the $\mathrm{P}^{+}$environment in the M247Ala $\rightarrow$ Asp mutant. The M247Ala $\rightarrow$ Asp mutation reveals the existence of an energetic and conformational coupling between donor and acceptor sides of the RC.

\section{INTRODUCTION}

Reaction center (RC) proteins of photosynthetic bacteria convert light energy into chemical free energy. This is achieved through a series of electron transfer reactions which lead, in about 200 ps, to a transmembrane charge separation between a dimer of bacteriochlorophyll molecules (primary electron donor $[\mathrm{P}]$ ) situated on the periplasmic side of the membrane and the primary quinone electron acceptor $\left(\mathrm{Q}_{\mathrm{A}}\right)$, at a distance of $\sim 30 \AA$ from $\mathrm{P}(1-4)$, bound in a relatively hydrophobic part of the cytoplasmic side of the protein. $\mathrm{Q}_{\mathrm{A}}$ functions as a one-electron acceptor and is never protonated in its semiquinone state $\left(\mathrm{Q}_{\mathrm{A}}{ }^{-}\right)$under physiological conditions. A secondary quinone electron acceptor, $\mathrm{Q}_{\mathrm{B}}$, is also found in the same region of the protein. Although chemically identical to $\mathrm{Q}_{\mathrm{A}}$ (both ubiquinone ${ }_{10}$ ) in Rhodobacter sphaeroides and Rhodobacter capsulatus, $\mathrm{Q}_{\mathrm{B}}$ functions as a two-electron gate, which accepts two electrons after successive photochemical events and two protons from the cytoplasmic bulk solvent to form the $\mathrm{Q}_{\mathrm{B}} \mathrm{H}_{2}$ species.

Whereas, in the past, a great deal of emphasis has been placed on probing the $\mathrm{Q}_{\mathrm{B}}$ environment because it is thought to be more relevant to the functional proton transfer events, more recent data have shown that the formation of $\mathrm{Q}_{\mathrm{A}}{ }^{-}$is a key step in initiating subsequent events in the protein complex (5-10). First, it has been shown recently that upon formation of $\mathrm{Q}_{\mathrm{A}}^{-}$, at neutral $\mathrm{pH}$, some residues present in the $\mathrm{Q}_{\mathrm{B}}$ environment and interacting with $\mathrm{Q}_{\mathrm{A}}{ }^{-}$shift their $\mathrm{p} K_{\mathrm{a}} \mathrm{s}$, leading to partial proton uptake that favors the $\mathrm{Q}_{\mathrm{A}}{ }^{-} \rightarrow \mathrm{Q}_{\mathrm{B}}$ electron transfer process (11). In addition, L212Glu (or alternatively, its cluster of acidic groups), which is at a distance of $5 \AA$ from $Q_{B}$, was shown to be directly involved in the same process at high $\mathrm{pH}(6,12,13)$. It is also of interest that the kinetics of proton uptake as a result of the formation of $\mathrm{Q}_{\mathrm{A}}{ }^{-}$has been suggested to reflect a gated process triggered by protein rearrangement events (5). This is reflected at the level of the $\mathrm{Q}_{\mathrm{A}}^{-} \rightarrow \mathrm{Q}_{\mathrm{B}}$ electron transfer rate $(7,14,15)$. Lastly, correlations between the arrangement of the $\mathrm{Q}_{B}$ pock- 
et (empty or occupied, presence of inhibitor, nearby mutations, etc.) and the physicochemical and spectroscopic properties of $\mathrm{Q}_{\mathrm{A}}$ have also been reported (16-21). Whereas this interdependence between the phenomena occurring at $\mathrm{Q}_{\mathrm{A}}$ and $\mathrm{Q}_{\mathrm{B}}$ has been demonstrated in these works, the possibility of similar linkage between $\mathrm{P}$ and $\mathrm{Q}_{\mathrm{A}}$ has also been recently suggested in the native RC (22).

In a similar way, as the formation of either semiquinone state leads to proton uptake by the protein, it was reported that, conversely, the formation of $\mathrm{P}^{+}$induces proton release (23-25). However, the way in which these protons are released is not clearly established. A pure electrostatic effect could account for a downward shift of the $\mathrm{p} K_{\mathrm{a}} \mathrm{s}$ of neighboring groups, therefore releasing protons. However, the hypothesis of a light-activated conformational change leading to the modification of the water content of the protein in the periplasmic region or to a different exposure of ionizable groups to the solvent (or both) has also been proposed (25).

In the present study, we have introduced acidic residues at positions M246 and M247 near $\mathrm{Q}_{\mathrm{A}}$ and have examined their effects on the function of the $\mathrm{Q}_{\mathrm{A}}$ site. The alanine residues at these two sites in the wild type (WT) RC are symmetry-related to L212Glu and L213Asp, respectively, in the $\mathrm{Q}_{\mathrm{B}}$ binding pocket $(26,27)$. We have examined $\mathrm{RC}$ derived from the photosynthetically incompetent M246AlaM247Ala $\rightarrow$ Glu-Asp double mutant and from two photocompetent phenotypic revertants of this strain; the revertants carry either the M246Ala $\rightarrow$ Glu or M247Ala $\rightarrow$ Asp single mutations.

We present for the first time, data on the $\mathrm{pH}$ dependencies of the stoichiometries of proton uptake by the $\mathrm{PQ}_{\mathrm{A}}^{-}$and $\mathrm{P}^{+} \mathrm{Q}_{\mathrm{A}}^{-}$states in $\mathrm{RC}$ mutants modified in the $\mathrm{Q}_{\mathrm{A}}$ protein pocket. Our data show that the introduction of ionizable residues in the $\mathrm{Q}_{\mathrm{A}}$ region substantially modifies the interactions of $\mathrm{Q}_{\mathrm{A}}$ with the protein groups over a wide $\mathrm{pH}$ range, and that the response of the protein is probably not localized. Furthermore, our results suggest that the protein environment of $\mathrm{P}^{+}$and $\mathrm{Q}_{\mathrm{A}}{ }^{-}$mutually interact over a distance of nearly $30 \AA$.

\section{EXPERIMENTAL PROCEDURES}

Bacterial strains and cell culture. Construction of the M246AlaM247Ala $\rightarrow$ Glu-Asp double mutant and isolation and genotypic characterization of the phenotypic revertants have been described previously $(28,29)$ (Fig. 1). Cells were grown semiaerobically in the dark on RPYE medium (27) containing $30 \mu \mathrm{g} \mathrm{mL}-1$ kanamycin to select the plasmid. RC were isolated as previously described (30).

Charge recombination kinetics. The kinetics of $\mathrm{P}^{+} \mathrm{Q}_{\mathrm{B}}{ }^{-} \rightarrow \mathrm{PQ}_{\mathrm{B}}$ and $\mathrm{P}^{+} \mathrm{Q}_{\mathrm{A}}{ }^{-} \rightarrow \mathrm{PQ}_{\mathrm{A}}$ charge recombinations were measured at $430 \mathrm{~nm}$ with a home-made spectrophotometer (31). The absorbance changes were triggered by saturating flashes from a Q-switch YAG laser at 532 $\mathrm{nm}$.

Electron transfer kinetics. The kinetics of the first electron transfer from $\mathrm{Q}_{\mathrm{A}}{ }^{-}$to $\mathrm{Q}_{\mathrm{B}}$ were measured at $750 \mathrm{~nm}$ in the electrochromic bandshift of the bacteriopheophytins. These experiments were done in the presence of $75 \mu M$ ubiquinone-6 $\left(\mathrm{UQ}_{6}\right)$ and $\sim 1 \mu M \mathrm{RC}$.

The kinetics of transfer of the second electron from $\mathrm{Q}_{\mathrm{A}}{ }^{-}$to $\mathrm{Q}_{\mathrm{B}}{ }^{-}$ were measured at $450 \mathrm{~nm}$ in the presence of reduced cytochrome $c$ $(20 \mu M), 75 \mu M \mathrm{UQ}_{6}$ and $\sim 2 \mu M \mathrm{RC}$.

$p H$ titrations. For the different $\mathrm{pH}$ titrations, buffers $(10 \mathrm{mM})$ used were 2-( $N$-morpholino)ethanesulfonic acid (MES; Sigma Chemical Co., St Louis, MO) between pH 5.5 and 6.5; 1,3bis[tris(hydroxymethyl)methylamino]propane (Sigma) between pH 6.3 and 9.5; and 3-(cyclohexylamino)-1-propanesulfonic acid (CAPS; Calbiochem) above pH 9.5.

Proton uptake. Proton uptake was measured by using a glass $\mathrm{pH}$

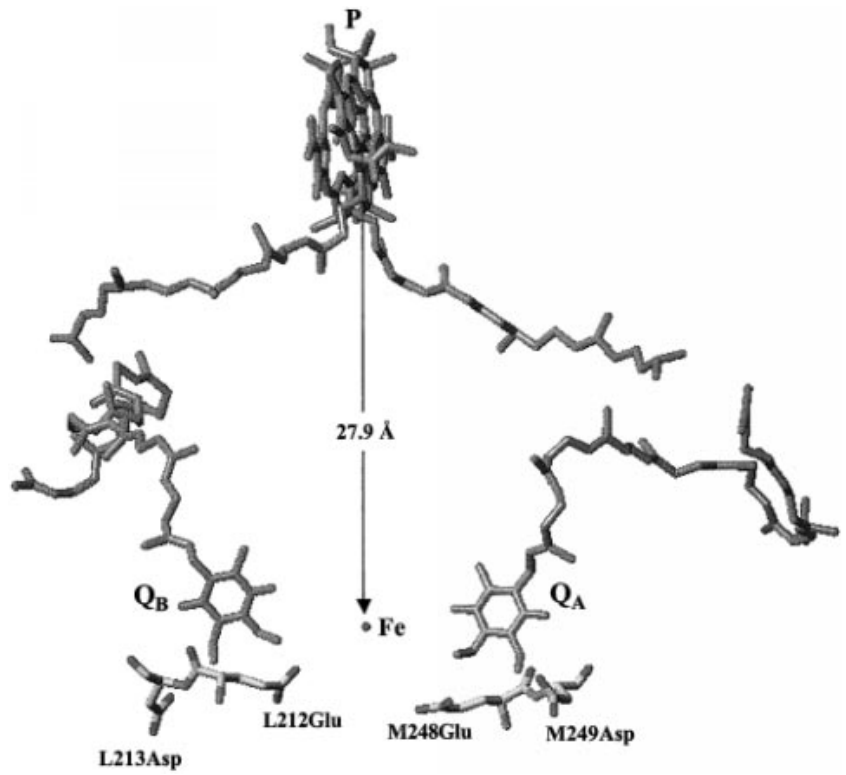

Figure 1. The relative positions of $\mathrm{P}, \mathrm{Q}_{\mathrm{A}}, \mathrm{Q}_{\mathrm{B}}$ and residues M248Glu, M249Asp, L212Glu and L213Asp are shown in the RC structure from $R$. sphaeroides (4) (PDB code: 1AIG) (equivalent residue numbers in $R$. capsulatus are M246 and M247, respectively). The distance between the midpoint of the dimer and the nonheme iron atom is indicated. The M248Ala $\rightarrow$ Glu and M249Ala $\rightarrow$ Asp mutated residues are located in a helical region; their side chains were modeled by using the program Turbo-Frodo. The modeled positions of the mutated residues are given in the absence of a major conformational change.

electrode and $\mathrm{pH}$-sensitive dyes (at $585 \mathrm{~nm}$, at the isosbestic point for $\mathrm{P}^{+} / \mathrm{P}$ absorbance changes). The conditions were as follows: $2 \mu M$ $\mathrm{RC}, 50 \mathrm{~m} M \mathrm{NaCl}, 0.03 \%$ Triton X-100, $200 \mu M$ ferrocene, $100 \mu M$ terbutryn and $20 \mu M$ dye (bromocresol purple, phenol red, cresol red or chlorophenol red, depending on the $\mathrm{pH}$ ). The $\mathrm{H}^{+} / \mathrm{Q}_{\mathrm{A}}{ }^{-}$proton uptake stoichiometries were measured in the presence of $100 \mu M$ ferrocene to reduce $\mathrm{P}^{+}$. In all measurements, the buffer concentrations were kept below $10 \mu M$ by extensive dialysis $\left(36 \mathrm{~h}\right.$ at $4^{\circ} \mathrm{C}$ ). In order to avoid any electrochromic dye effect, the buffered $(\sim 10$ $\mathrm{m} M$ MES, MOPS, TRIS or CAPS) traces were systematically subtracted from the unbuffered traces.

The data points presented in Figs. 4 and 5 for the $\mathrm{H}^{+} / \mathrm{Q}_{\mathrm{A}}{ }^{-}$and $\mathrm{H}^{+} / \mathrm{P}^{+} \mathrm{Q}_{\mathrm{A}}^{-}$proton uptake represent the average of several (up to 12 ) measurements performed with different RC preparations.

\section{RESULTS}

pH dependence of $-\Delta G_{\mathrm{AB}}{ }^{\circ}$, the free energy barrier between $Q_{A}^{-}$and $Q_{B}$

The $\mathrm{pH}$ dependencies of the $-\Delta G_{\mathrm{AB}}{ }^{\circ}$ values in WT RC (reproduced from [32]) and in RC of the M246Ala $\rightarrow$ Glu, M247Ala $\rightarrow$ Asp and M246Ala-M247Ala $\rightarrow$ Glu-Asp mutants are presented in Fig. 2. The values of $-\Delta G_{\mathrm{AB}}{ }^{\circ}$ at each $\mathrm{pH}$ were calculated from the rate constants of the $\mathrm{P}^{+} \mathrm{Q}_{\mathrm{A}}{ }^{-}$ $\left(k_{\mathrm{AP}}\right)$ and $\mathrm{P}^{+} \mathrm{Q}_{\mathrm{B}}{ }^{-}\left(k_{\mathrm{BP}}\right)$ charge recombination reactions for each type of RC. No more than $30 \%$ variability was observed in the $k_{\mathrm{AP}}$ rate constant values between the various RC. To calculate the $-\Delta G_{\mathrm{AB}}{ }^{\circ}$ values, we used the formula $-\Delta G_{\mathrm{AB}}{ }^{\circ}=-k T \ln \left(K_{2}\right)$, where $k$ represents the Boltzmann constant, $T$ the absolute temperature and $K_{2}$ the one-electron equilibrium constant between the $\mathrm{P}^{+} \mathrm{Q}_{\mathrm{A}}{ }^{-}$and $\mathrm{P}^{+} \mathrm{Q}_{\mathrm{B}}{ }^{-}$free energy states. $K_{2}$ is derived from the formula initially suggested (33) 


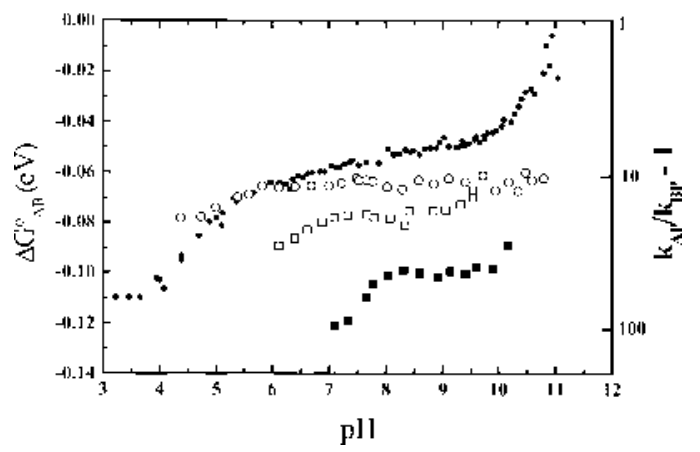

Figure 2. $\mathrm{pH}$ dependence of the free energy gap, $-\Delta G_{\mathrm{AB}}^{\circ}$, between the $\mathrm{Q}_{\mathrm{A}}{ }^{-}$and $\mathrm{Q}_{\mathrm{B}}{ }^{-}$states in the $\mathrm{RC}(\sim 1 \mu M)$ of M246Ala $\rightarrow$ Glu $(0)$,

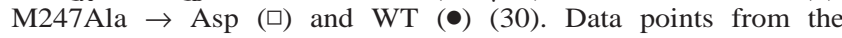

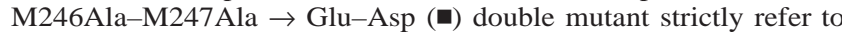
the right axis. The very slow $\mathrm{P}^{+} \mathrm{Q}_{\mathrm{B}}{ }^{-} \rightarrow \mathrm{PQ}_{\mathrm{B}}$ decay observed in this mutant suggests a direct route (not through $\mathrm{Q}_{\mathrm{A}}$ ) for the charge recombination process. The $-\Delta G_{\mathrm{AB}}{ }^{\circ}$ values are deduced from the rates of the $\mathrm{P}^{+} \mathrm{Q}_{\mathrm{A}}{ }^{-}$and $\mathrm{P}^{+} \mathrm{Q}_{\mathrm{B}}{ }^{-}$charge recombination processes. Conditions: $430 \mathrm{~nm}, 0.05 \%$ LDAO $(\mathrm{pH} 7-11)$ or $0.03 \%$ Triton X-100 $(\mathrm{pH}$ 5-8), $75 \mathrm{mM} \mathrm{UQ}_{6}, 21^{\circ} \mathrm{C}$. Buffers $(10 \mathrm{mM})$, see text.

$$
1+K_{2}=k_{\mathrm{AP}} / k_{\mathrm{BP}}
$$

The $p H$ dependence of $-\Delta \mathrm{G}_{A B}$ for the M246Ala $\rightarrow$ Glu mutant $R C$ ( $O$ in Fig. 2). Below $\mathrm{pH} \sim 6,-\Delta G_{\mathrm{AB}}^{\circ}$ values display a net decrease from about $-65 \mathrm{meV}$ at $\mathrm{pH} \sim 6.0$ to about $-75 \mathrm{meV}$ at $\mathrm{pH}$ 4.6. Interestingly, above $\mathrm{pH}$ 6.0, $-\Delta G_{\mathrm{AB}}{ }^{\circ}$ is no longer $\mathrm{pH}$-dependent and remains constant

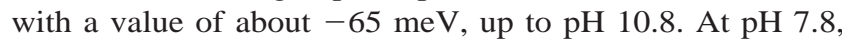
$k_{\mathrm{BP}}$ equals $\sim 0.70 \mathrm{~s}^{-1}$.

The $p H$ dependence of $-\Delta \mathrm{G}_{A B}{ }^{\circ}$ for the M247Ala $\rightarrow$ Asp mutant $\mathrm{RC}$ ( $\square$ in Fig. 2). A plateau is observed between $\mathrm{pH}$ 7 and 9 with a value of about $-80 \mathrm{meV}$. This value is slightly more negative than that of the M246Ala $\rightarrow$ Glu mutant RC. Below $\mathrm{pH} 7,-\Delta G_{\mathrm{AB}}{ }^{\circ}$ smoothly titrates to reach a value of $-90 \mathrm{meV}$ at $\mathrm{pH}$ 5.9. Above $\mathrm{pH} 9$, an increase of $-\Delta G_{\mathrm{AB}}{ }^{\circ}$ is observed, reaching a value of $-70 \mathrm{meV}$ at $\mathrm{pH} 9.5$. Because of the instability of the RC from the M247Ala $\rightarrow$ Asp mutant and the low occupancy of the $\mathrm{Q}_{\mathrm{B}}$ site at very high $\mathrm{pH}$, it was difficult to collect data above this $\mathrm{pH}$.

The M246Ala-M247Ala $\rightarrow$ Glu-Asp double mutant RC. In this case we have displayed, in Fig. 2, the $\mathrm{pH}$ dependence of the $k_{\mathrm{AP}} / k_{\mathrm{BP}}-1$ term and not that of $-\Delta G_{\mathrm{AB}}{ }^{\circ}$. This should be done because the small values of $k_{\mathrm{BP}}$ measured in this mutant suggest that an important part of the $\mathrm{P}^{+} \mathrm{Q}_{\mathrm{B}}{ }^{-}$charge recombination process may occur through a direct pathway between $\mathrm{P}$ and $\mathrm{Q}_{\mathrm{B}}$ instead of the indirect route via repopulation of the $\mathrm{P}^{+} \mathrm{Q}_{\mathrm{A}}{ }^{-}$state (34). Indeed, the negative (or partly negative) charges carried by the mutations present in the $\mathrm{Q}_{\mathrm{A}}$ environment in the double mutant destabilized the $\mathrm{Q}_{\mathrm{A}}{ }^{-}$state. In other words, the midpoint redox potential of the $\mathrm{Q}_{\mathrm{A}}{ }^{-} / \mathrm{Q}_{\mathrm{A}}$ couple is very likely to be more negative in the mutant than in the WT. As a consequence, $-\Delta G_{\mathrm{AB}}{ }^{\circ}$ notably increases in the mutant, leading to a substantial decrease of $k_{\mathrm{BP}}$. Indeed, the observed $k_{\mathrm{BP}}$ value is close to the value previously determined for the rate of the direct pathway (34). At $\mathrm{pH} 8$, $k_{\mathrm{BP}} \sim 0.14 \mathrm{~s}^{-1}\left(k_{\mathrm{AP}} / k_{\mathrm{BP}}-1=\sim 55\right)$. In the $\mathrm{pH}$ range $8-10$, the $\left(k_{\mathrm{AP}} / k_{\mathrm{BP}}-1\right)$ term is roughly constant. A sharp and continuous decrease is detected below $\mathrm{pH}$ 8. At $\mathrm{pH} 7$, this factor is about 130. At this $\mathrm{pH}$, the $-\Delta G_{\mathrm{AB}}{ }^{\circ}$ value in this mutant
Table 1. Energetic and kinetic parameters of electron transfer in the WT and the RC mutants at $\mathrm{pH} 7.8$

\begin{tabular}{lccc}
\hline \multicolumn{1}{c}{ Strain } & $\begin{array}{c}k_{\mathrm{BP}}\left(\mathrm{s}^{-1}\right) \\
( \pm 10 \%)\end{array}$ & $\begin{array}{c}k_{\mathrm{AB}}(1) \\
( \pm 10 \%)\end{array}$ & $\begin{array}{c}k_{\mathrm{AB}}(2) \\
\left(\mathrm{s}^{-1}\right) \\
( \pm 10 \%)\end{array}$ \\
\hline WT & 0.90 & 15400 & 1900 \\
M246Ala $\rightarrow$ Glu & 0.70 & 12500 & 2150 \\
M247Ala $\rightarrow$ Asp & 0.31 & 7400 & 2000 \\
M246Ala/M247Ala $\rightarrow$ Glu/Asp & 0.11 & 6250 & 1400 \\
\hline
\end{tabular}

must, therefore, be greater than $120 \mathrm{meV}$, i.e. more than 60 meV greater than that measured in WT RC.

\section{Rate of transfer of the first electron in mutant RC}

The rate of the first electron transfer reaction from $\mathrm{Q}_{\mathrm{A}}{ }^{-}$to $\mathrm{Q}_{\mathrm{B}}$ was measured for the $\mathrm{RC}$ mutants, at $\mathrm{pH} 7.8$ and 750 $\mathrm{nm}$, which monitors the electrochromic bandshift of both bacteriopheophytins. We previously measured this rate in $\mathrm{RC}$ of WT $R$. capsulatus and found it to be $(65 \mu \mathrm{s})^{-1}(30)$. In mutant RC carrying the M246Ala $\rightarrow$ Glu, M247Ala $\rightarrow$ Asp or M246Ala-M247Ala $\rightarrow$ Glu-Asp mutations, we measured, respectively, $(80 \pm 10 \mu \mathrm{s})^{-1},(135 \pm 20 \mu \mathrm{s})^{-1}$ and $(160 \pm 20 \mu \mathrm{s})^{-1}$ (Table 1$)$. The observed modification of the $-\Delta G_{\mathrm{AB}}{ }^{\circ}$ values in the mutant $\mathrm{RC}$ is, therefore, not accompanied by significant changes of the first electron transfer rate. The first electron transfer process from $\mathrm{Q}_{\mathrm{A}}{ }^{-}$to $\mathrm{Q}_{\mathrm{B}}$ has been suggested to be kinetically limited by protonation or conformational rearrangements (or both) of the protein (35). Therefore, one does not expect $k_{\mathrm{AB}}(1)$ to sharply vary (as in a Marcus-type plot) as a function of $-\Delta G_{\mathrm{AB}}{ }^{\circ}$. This explains the weak $k_{\mathrm{AB}}(1)$ variations observed here between the WT and the various mutants.

\section{pH dependence of the second electron transfer rate, $k_{\mathrm{AB}}(2)$, in the mutant $\mathrm{RC}$}

The $\mathrm{pH}$ dependence of the rate for the second electron transfer reaction in the mutant $\mathrm{RC}$ is shown in Fig. 3, together with that previously reported for the WT (32). No major

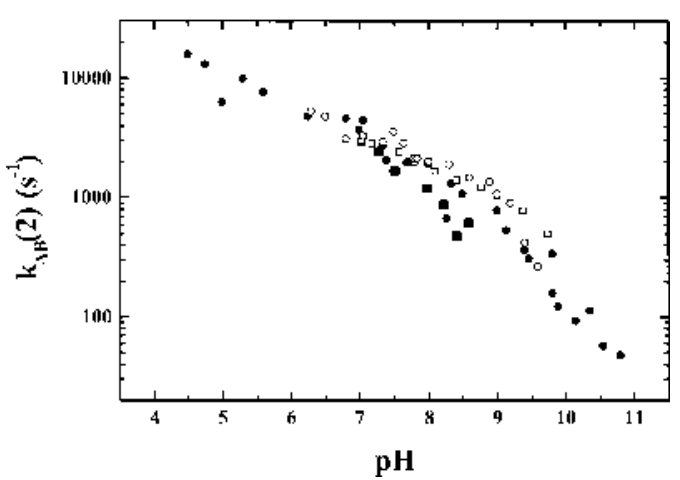

Figure 3. $\mathrm{pH}$ dependence of the rates of the second electron transfer from $\mathrm{Q}_{\mathrm{A}}{ }^{-}$to $\mathrm{Q}_{\mathrm{B}}{ }^{-}(450 \mathrm{~nm})$ in the $\mathrm{RC}(\sim 2 \mu M)$ for M246Ala $\rightarrow$ Glu $(\mathrm{O})$, M247Ala $\rightarrow$ Asp (ㅁ) and M246Ala-M247Ala $\rightarrow$ Glu-Asp (ロ) mutants. The data points from the WT RC $(\bullet)$ were taken from (32). Conditions: $0.05 \%$ LDAO or $0.03 \%$ Triton X-100 buffers as indicated in the text. $20 \mu M$ cytochrome $c, 200 \mu M$ sodium ascorbate, $75 \mu M \mathrm{UQ}_{6}$. Buffers $(10 \mathrm{mM})$, see text. 
Julia Tandori et al.

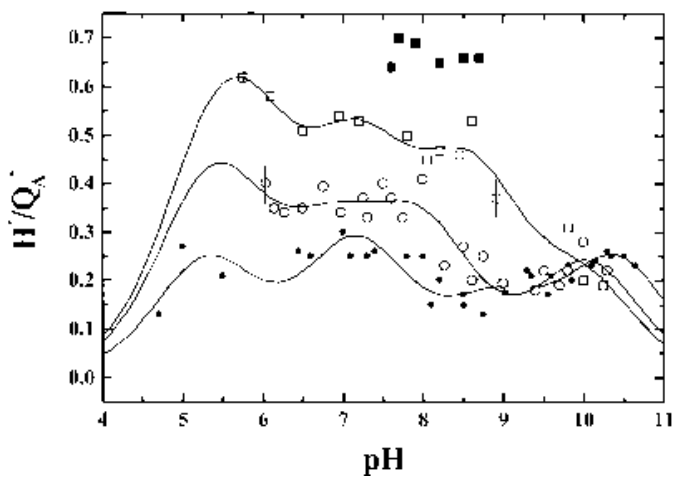

Figure 4. $\mathrm{pH}$ dependence of the stoichiometries of proton uptake by the $\mathrm{PQ}_{\mathrm{A}}{ }^{-}$state in RC of M246Ala $\rightarrow$ Glu (O), M247Ala $\rightarrow$ Asp $(\square)$ and M246Ala-M247Ala $\rightarrow$ Glu-Asp (匹) mutants. The previously measured WT data points $(\bullet)$ (36) are also shown for comparison. The lines represent the fittings of the stoichiometry of proton uptake using Eq. 2, with the assumption of four groups with apparent $\mathrm{p} K_{\mathrm{a}}$. Conditions: $\sim 2 \mu M \mathrm{RC}, 0.03 \%$ Triton X-100, $100 \mu M$ ferrocene, $50-$ $75 \mu M \mathrm{UQ}_{6}, 50 \mathrm{~m} M \mathrm{NaCl}, 100 \mu M$ terbutryn and $40 \mu M$ dye (bromocresol purple, phenol red, cresol red or chlorophenol red, depending on the $\mathrm{pH})$. Buffers $(<10 \mu M)$, see text.

changes are observed - the values of $k_{\mathrm{AB}}(2)$ obtained for RC of the M246Ala $\rightarrow$ Glu and M247Ala $\rightarrow$ Asp mutants are almost superimposable with those of the WT between $\mathrm{pH} 6$ and 8. The rate is the same for all at $\mathrm{pH} 7$. However, the slopes of the $\mathrm{pH}$ dependence for both the M246Ala $\rightarrow$ Glu and M247Ala $\rightarrow$ Asp mutant RC are slightly smaller than the slopes for the WT RC. As a result, slightly higher values of $k_{\mathrm{AB}}(2)$ are observed for the single mutants at high $\mathrm{pH}$, i.e. above the break point for the WT RC. In the case of the M246Ala-M247Ala $\rightarrow$ Glu-Asp double mutant, the steeper slope indicates that $k_{\mathrm{AB}}(2)$ values in this mutant are nearly two times smaller than in the WT or single mutant RC (Table 2).

\section{pH dependence of $\mathrm{H}^{+} / \mathrm{Q}_{\mathrm{A}}^{-}$proton uptake}

The $\mathrm{pH}$ dependencies of the $\mathrm{H}^{+} / \mathrm{Q}_{\mathrm{A}}^{-}\left(\mathrm{PQ}_{\mathrm{A}}{ }^{-}\right.$state) proton uptake stoichiometries, as measured for the WT RC (previously published in [36]) and for the mutant RC are displayed in Fig. 4. These data have been obtained in the presence of terbutryn (inhibitor of the $\mathrm{Q}_{\mathrm{A}}^{-} \rightarrow \mathrm{Q}_{\mathrm{B}}$ electron transfer process) and ferrocene (electron donor to $\mathrm{P}^{+}$). In each case, the lines drawn through the data points represent a fit, assuming that the net proton uptake is the sum of proton binding by independent ionizable residues, represented by four apparent $\mathrm{p} K_{\mathrm{a}} \mathrm{s}$. Assuming that an ionizable group, i, interacting with $\mathrm{Q}_{\mathrm{A}}{ }^{-}$, undergoes a $\mathrm{p} K_{\mathrm{a}}$ shift from in the $\mathrm{Q}_{\mathrm{A}}$ state to upon $\mathrm{Q}_{\mathrm{A}}{ }^{-}$ formation, the net proton binding may be expressed as

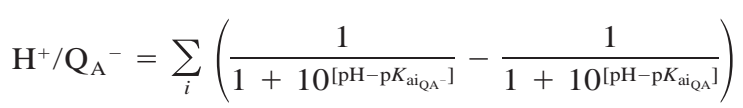

This is the simplest model that fits the data. However, because we are aware of the limitation of this model, in the following discussion we only considered, for comparison, the highest $\mathrm{pH} \mathrm{p} K_{\mathrm{a}}$ group, called group ${ }_{\text {high }}$. In each case (the $\mathrm{WT}$ and the two single mutants), we called $\mathrm{p} K_{\text {highQA }}$ and $\mathrm{p} K_{\text {highQA }}{ }^{-}$the respective values of this $\mathrm{p} K a$ in the $\mathrm{Q}_{\mathrm{A}}$ and $\mathrm{Q}_{\mathrm{A}}{ }^{-}$forms, and $\Delta \mathrm{p} K_{\text {high }}=\mathrm{p} K_{\text {highQA }}{ }^{-}-\mathrm{p} K_{\text {highQA }}$.

The M246Ala $\rightarrow$ Glu and M247Ala $\rightarrow$ Asp mutants. As

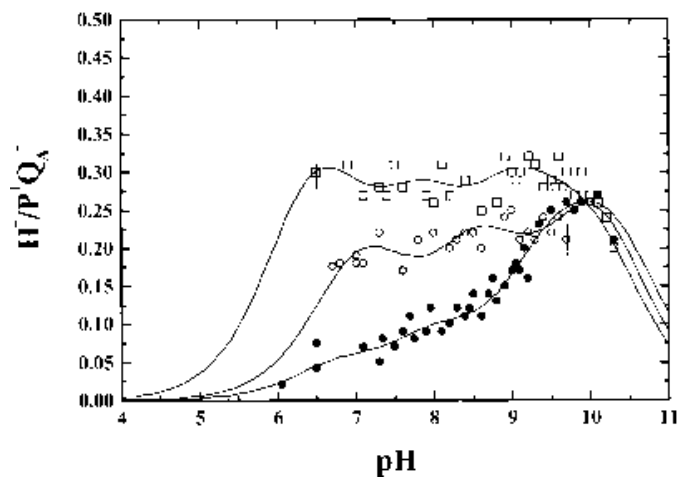

Figure 5. $\mathrm{pH}$ dependence of the stoichiometries of proton uptake by the $\mathrm{P}^{+} \mathrm{Q}_{\mathrm{A}}^{-}$state in RC of M246Ala $\rightarrow$ Glu (O), M247Ala $\rightarrow$ Asp

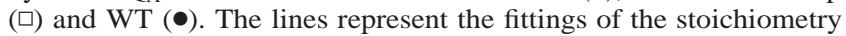
of proton uptake using Eq. 2, with the assumption of four groups with apparent $\mathrm{p} K_{\mathrm{a}}$. Conditions: same as those in Fig. 4, but no ferrocene. Buffers $(<10 \mu M)$, see text.

shown in Fig. 4, in a wide $\mathrm{pH}$ region, the $\mathrm{H}^{+} / \mathrm{Q}_{\mathrm{A}}{ }^{-}$proton uptakes for the M246Ala $\rightarrow$ Glu and the M247Ala $\rightarrow$ Asp RC mutants are notably larger than in the WT. In the $\mathrm{pH}$ range $6-8$, about $0.35-0.40$ and $0.65-0.45 \mathrm{H}^{+}$are respectively taken up in both mutants, $\left(\sim 0.20-0.25 \mathrm{H}^{+}\right.$in the WT). Because of the low occupancy of the $\mathrm{Q}_{\mathrm{A}}$ pocket (in the $\mathrm{Q}_{\mathrm{A}}{ }^{-}$ state) above $\mathrm{pH} 9.7$, in $\mathrm{RC}$ of these mutants, the intrinsic $\mathrm{H}^{+} / \mathrm{Q}_{\mathrm{A}}{ }^{-}$uptake measurements become more difficult. Therefore, to reliably achieve these high $\mathrm{pH}$ values, we repeated them five times more than the measurements done at neutral $\mathrm{pH}$. At high $\mathrm{pH}$, group high -whose apparent $\mathrm{p} K_{\mathrm{a}} \mathrm{s}$ in the WT are $\sim 10.20\left(\mathrm{p} K_{\text {highQA }}\right)$ and $\sim 10.60\left(\mathrm{p}_{\text {highQA }^{-}}\right)$-is also present in the two single mutants with similar values for $\Delta \mathrm{p} K_{\text {high }}$ $(\sim 0.3-0.4)$ as in the WT RC.

The M246Ala-M247Ala $\rightarrow$ Glu-Asp double mutant. Because of the low quinone occupancy at high $\mathrm{pH}$ and the instability of this mutant $\mathrm{RC}$ below $\mathrm{pH} 7.5$, we could measure the $\mathrm{H}^{+} / \mathrm{Q}_{\mathrm{A}}^{-}$proton uptake only in the $\mathrm{pH}$ range $7.5-$ 8.8. We found proton uptake values as high as $0.65-0.72$ $\mathrm{H}^{+}$. It is of interest that the difference in the stoichiometry of proton binding between this mutant RC and the WT measured at the same $\mathrm{pH}\left(\right.$ e.g. at $\mathrm{pH} 8,0.70-0.18=0.52 \mathrm{H}^{+}$/ $\mathrm{Q}_{\mathrm{A}}{ }^{-}$) roughly represents the sum of the additional $\mathrm{H}^{+} / \mathrm{Q}_{\mathrm{A}}{ }^{-}$ uptake observed in the M246Ala $\rightarrow$ Glu $(\sim 0.17)$ and in the M247Ala $\rightarrow$ Asp mutant $(\sim 0.30)$ compared to the WT.

\section{pH dependence of the $\mathrm{H}^{+} / \mathrm{P}^{+} \mathbf{Q}_{\mathrm{A}}{ }^{-}$proton uptake}

The $\mathrm{pH}$ dependencies of the $\mathrm{H}^{+} / \mathrm{P}^{+} \mathrm{Q}_{\mathrm{A}}{ }^{-}\left(\mathrm{P}^{+} \mathrm{Q}_{\mathrm{A}}{ }^{-}\right.$state $)$proton uptake stoichiometries, measured in the presence of terbutryn but in the absence of ferrocene, for RC of the WT, the M246Ala $\rightarrow$ Glu mutant and the M247Ala $\rightarrow$ Asp mutant are displayed in Fig. 5. The data were fitted in a similar way as for the $\mathrm{H}^{+} / \mathrm{Q}_{\mathrm{A}}^{-}$data points (see earlier).

The wild type. The $\mathrm{H}^{+} / \mathrm{P}^{+} \mathrm{Q}_{\mathrm{A}}^{-}$stoichiometry shown here for the native $R$. capsulatus $\mathrm{RC}$ has not been reported before. The profile of the curve is very similar to that previously shown for the RC from $R$. sphaeroides $(23,24)$. The maximum amplitude of proton uptake measured here near $\mathrm{pH} 10$, $\sim 0.27 \mathrm{H}^{+}$, is lower than that of $R$. sphaeroides $\mathrm{RC}(\sim 0.4$ $\mathrm{H}^{+}$) at $\mathrm{pH}$ 10. The titration of $\mathrm{H}^{+} / \mathrm{P}^{+} \mathrm{Q}_{\mathrm{A}}{ }^{-}$leads to a similar behavior at high $\mathrm{pH}$ as was shown previously for $\mathrm{H}^{+} / \mathrm{Q}_{\mathrm{A}}{ }^{-}$ 
Photochemistry and Photobiology, 2002, 75(2)

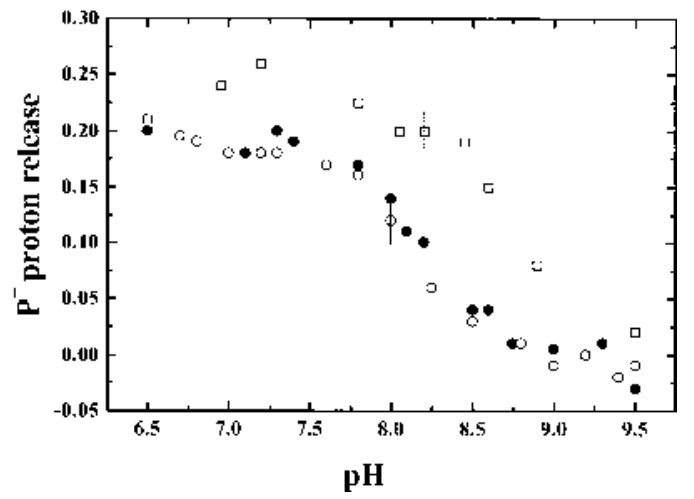

Figure 6. $\mathrm{H}^{+} / \mathrm{P}^{+}$apparent proton release (shown in positive) obtained by subtracting the $\mathrm{H}^{+} / \mathrm{PQ}_{\mathrm{A}}{ }^{-}$curves of Fig. 5 from the $\mathrm{H}^{+} /$ $\mathrm{P}^{+} \mathrm{Q}_{\mathrm{A}}{ }^{-}$curves of Fig. 4. The error bars reflect the respective error bars of each set of measurements. (०), M246Ala $\rightarrow$ Glu mutant; ( $\square$ ), M247Ala $\rightarrow$ Asp mutant; and $(\bullet)$, WT.

with, however, a notable decrease of about $0.5 \mathrm{pH}$ units of both $\mathrm{p} K_{\text {highQA }}$ and $\mathrm{p} K_{\text {highQA }}{ }^{-}$but with a comparable value for $\Delta \mathrm{p} K_{\text {high }}(\sim 0.43)$. The $\mathrm{H}^{+} / \mathrm{P}^{+} \mathrm{Q}_{\mathrm{A}}^{-}$titration below $\mathrm{pH} 9$ shows a continuous decrease. At $\mathrm{pH} 6$, almost no net protons are taken up by the $\mathrm{P}^{+} \mathrm{Q}_{\mathrm{A}}^{-}$state.

The M246Ala $\rightarrow$ Glu and M247Ala $\rightarrow$ Asp mutants. Similarly to the WT, RC of the M246Ala $\rightarrow$ Glu and the M247Ala $\rightarrow$ Asp mutants display similar patterns of $\mathrm{H}^{+} / \mathrm{Q}_{\mathrm{A}}{ }^{-}$ and $\mathrm{H}^{+} / \mathrm{P}^{+} \mathrm{Q}_{\mathrm{A}}{ }^{-}$proton uptake at high $\mathrm{pH}$. Indeed, compared to the $\mathrm{H}^{+} / \mathrm{Q}_{\mathrm{A}}^{-}$curves, no changes of the $\Delta \mathrm{p} K_{\text {high }}(\sim 0.40)$ occur in the presence of $\mathrm{P}^{+}$as well as for the $\mathrm{p} K_{\text {highQA }}$ and $\mathrm{p}_{\text {highQA }}{ }^{-}$values themselves. Below $\mathrm{pH}$ 9.2, the overall amount of proton uptake is notably lower than in the $\mathrm{Q}_{\mathrm{A}}{ }^{-}$ state. Compared to the WT, both mutant RC take up more protons. Consistent with the observation for the $\mathrm{H}^{+} / \mathrm{Q}_{\mathrm{A}}{ }^{-}$ curves, the M247Ala $\rightarrow$ Asp mutant takes even more than the M246Ala $\rightarrow$ Glu mutant in the $\mathrm{pH}$ range 6.5-9.0.

\section{Proton release by $\mathbf{P}^{+}$in native and mutant $\mathbf{R C}$}

The difference between the $\mathrm{H}^{+} / \mathrm{P}^{+} \mathrm{Q}_{\mathrm{A}}{ }^{-}$and $\mathrm{H}^{+} / \mathrm{Q}_{\mathrm{A}}{ }^{-}$proton uptake curves measured for the $\mathrm{RC}$ from each of the three strains affords the contribution resulting from proton release following the formation of the $\mathrm{P}^{+}$state. The difference curves are presented in Fig. 6 for the WT, the M246Ala $\rightarrow$ Glu mutant and the M247Ala $\rightarrow$ Asp mutant. As previously reported for $R$. sphaeroides RC $(23,24)$, the proton release caused by $\mathrm{P}^{+}$formation is nearly zero above $\mathrm{pH} 9$, and it continuously increases at lower $\mathrm{pH}$ to reach a value of about $0.3 \mathrm{H}^{+}$released per $\mathrm{P}^{+}$at $\mathrm{pH}$ 6.5. Our present data obtained for $R$. capsulatus $\mathrm{RC}$ agree with these figures, although the absolute value of $\mathrm{H}^{+} / \mathrm{P}^{+}$at $\mathrm{pH} 6.5$ is lowered to $\sim 0.22$.

The attribution of these curves to the $\mathrm{pH}$ dependence of the $\mathrm{H}^{+} / \mathrm{P}^{+}$proton release implicitly assumes that protonation events occurring upon $\mathrm{P}^{+}$formation do not depend on the redox state of $\mathrm{Q}_{\mathrm{A}}$. Likewise, it should also be assumed that proton uptake induced by $\mathrm{Q}_{\mathrm{A}}{ }^{-}$formation is the same in the $\mathrm{P}$ and $\mathrm{P}^{+}$states. Yet, our data show that this is not the case. The patterns observed for the $\mathrm{H}^{+} / \mathrm{P}^{+}$proton release are nearly the same for RC of the WT and the M246Ala $\rightarrow$ Glu mutant. At variance, substantial additional proton release is detected in the M247Ala $\rightarrow$ Asp mutant compared to the RC of the WT and the M246Ala $\rightarrow$ Glu mutant. This effect is dominant around $\mathrm{pH} 8.5$.

\section{DISCUSSION}

The electrostatic and functional connections between the protein environments of the two quinone species have previously been highlighted $(11,16,18,21,33,37-40)$. The idea that the formation of the $\mathrm{Q}_{\mathrm{A}}{ }^{-}$species might be an important step for the function of the RC complex was initially suggested on the basis of experiments performed with RC isolated from $R$. capsulatus (10) and with $R$. sphaeroides RC incorporated in lipid monolayers (8). These studies attributed the functional connection between $\mathrm{Q}_{\mathrm{A}}{ }^{-}$and the secondary quinone site to residue L212Glu or to an acidic cluster in which L212Glu participates (or to both). In addition, proton uptake measurements attributed the electrostatic response of the protein to the formation of $\mathrm{Q}_{\mathrm{A}}^{-}$to groups localized in the $\mathrm{Q}_{\mathrm{B}}$ environment or to groups involved in the network connecting $\mathrm{Q}_{\mathrm{A}}{ }^{-}$and $\mathrm{Q}_{\mathrm{B}}{ }^{-}$(or to both) $(5,11,37)$. Because all these studies pointed to the predominant role of L212Glupossibly in conjunction with its participation in a cluster of strongly interacting acidic residues including L213Asp and L210Asp-we were prompted to study how, conversely, the introduction of ionizable residues at the analogous positions in the $\mathrm{Q}_{\mathrm{A}}$ pocket would be experienced by the protein.

Energetic effects of the introduction of Glu or Asp (or both) in position M246 or M247 (or both). The measure of the $\mathrm{pH}$ dependence for proton uptake resulting from the formation of the $\mathrm{Q}_{\mathrm{A}}{ }^{-}$or $\mathrm{Q}_{\mathrm{B}}{ }^{-}$state allows us to probe the specific energetic effects of acidic residues on nearby or distant protein environments. As compared to the WT, in RC of the M246Ala $\rightarrow$ Glu and M247Ala $\rightarrow$ Asp mutants, the main trend is a notable increase of the $\mathrm{H}^{+} / \mathrm{Q}_{\mathrm{A}}{ }^{-}$and $\mathrm{H}^{+} / \mathrm{P}^{+} \mathrm{Q}_{\mathrm{A}}{ }^{-}$ proton uptake values over quite extended $\mathrm{pH}$ regions $(5.8-$ 10.5 and 6.5-10.2, respectively)(see Fig. 2).

Most of the literature for proton uptake comes from measurements made with WT RC following the light-induced formation of the $\mathrm{Q}_{\mathrm{A}}{ }^{-}$or $\mathrm{Q}_{\mathrm{B}}{ }^{-}$states. Some data have been reported for RC from mutants of $R$. capsulatus $(6,41)$ and $R$. sphaeroides $(13,42)$ that lack L212Glu. In all these studies, the absence of $\mathrm{L} 212 \mathrm{Glu}$ resulted in the drop of proton uptake above $\mathrm{pH} 8$ in the $\mathrm{Q}_{\mathrm{A}}{ }^{-}$as well as the $\mathrm{Q}_{\mathrm{B}}{ }^{-}$states; neither pattern of proton uptake was affected at neutral and low $\mathrm{pH}$. However, infrared spectroscopy experiments, which are more specific to follow the ionization state of a particular carboxylic group, have rather suggested that L212Glu is partly ionized at neutral $\mathrm{pH}$, and that the ionization of L212Glu takes place over a wide $\mathrm{pH}$ range (43). In strong support of this hypothesis, electrostatic calculations have shown that the titration of carboxylic groups, especially within clusters of interacting acidic residues, is necessarily extended over very wide $\mathrm{pH}$ ranges $(38-40,44-48)$. In other words, these calculations have shown that the titrations of these groups do not follow classical Handerson-Hasselbach curves, but rather that a particular group may statistically carry part of a proton over several $\mathrm{pH}$ units.

It is likely that M246Glu and M247Asp have similar behavior in the $\mathrm{Q}_{\mathrm{A}}$ pocket. This is probably why the increase of $\mathrm{H}^{+} / \mathrm{Q}_{\mathrm{A}}^{-}$and $\mathrm{H}^{+} / \mathrm{P}^{+} \mathrm{Q}_{\mathrm{A}}^{-}$values in the M246Ala $\rightarrow$ Glu and 
M247Ala $\rightarrow$ Asp single mutants extends over the whole $\mathrm{pH}$ range measured here.

The small but constantly higher $-\Delta G_{\mathrm{AB}}^{\circ}$ value $(\sim 20 \mathrm{meV})$ measured in the M247Ala $\rightarrow$ Asp mutant (Fig. 2) as compared to the WT suggests that M247Asp is partly ionized over the whole $\mathrm{pH}$ range measured here. A full ionization of M247Asp and a distance of about $6 \AA$ between $\mathrm{Q}_{\mathrm{A}}{ }^{-}$and the carboxyl group of M247Asp would be consistent with a dielectric constant value higher than 80 . This obviously too high value strongly suggests that the amount of ionization of M247Asp is very low.

On the other hand, in the M246Ala $\rightarrow$ Glu mutant, Glu is likely to be protonated below $\mathrm{pH} 6$ and more and more deprotonated at higher $\mathrm{pH}$. As shown in Fig. $2,-\Delta G_{\mathrm{AB}}{ }^{\circ}$ in the M246Ala $\rightarrow$ Glu RC is $\mathrm{pH}$-independent from $\mathrm{pH} \sim 6.0$ to $\sim 10.8$. In this mutant $\mathrm{RC},-\Delta G_{\mathrm{AB}}{ }^{\circ}$ is about the same as that of the WT at pH 6. However, the smooth increase of $-\Delta G_{\mathrm{AB}}{ }^{\circ}$ observed in the WT up to $\mathrm{pH} 9.7$ and its strong increase above this $\mathrm{pH}$ value are absent in this mutant. This observation can be explained if M246Glu has a similar $\mathrm{pH}$ titration as the acidic cluster (L210Asp-L212Glu-L213Asp) in the $\mathrm{Q}_{\mathrm{B}}{ }^{-}$pocket. Indeed, the electrostatic effect of M246Glu must be to increase the free energy level of the $\mathrm{Q}_{\mathrm{A}}{ }^{-}$state to a similar extent and $\mathrm{pH}$ dependence as the above cluster does on $\mathrm{Q}_{\mathrm{B}}{ }^{-}$. Therefore, the combination of both effects compensate and lead to the lack of a $\mathrm{pH}$ dependence for $-\Delta G_{\mathrm{AB}}{ }^{\circ}$ at high $\mathrm{pH}$. In support of this effect (ionization of M246Glu and increase of the $\mathrm{Q}_{\mathrm{A}}{ }^{-}$free energy state), we have noticed that the occupancy of the $\mathrm{Q}_{\mathrm{A}}$ site continuously decreases with $\mathrm{pH}$ in this mutant, with a dependence that roughly matches that of the ratio between the $-\Delta G_{\mathrm{AB}}{ }^{\circ}$ curves of $\mathrm{RC}$ of the WT and of the M246Ala $\rightarrow$ Glu mutant (data not shown). The increasing charge on M246Glu as $\mathrm{pH}$ increases is likely to progressively destabilize the $\mathrm{Q}_{\mathrm{A}}{ }^{-}$state and may concomitantly displace $\mathrm{Q}_{\mathrm{A}}{ }^{-}$from its site. It is of interest to associate this effect to recent calculations, which have suggested that the proximal position of $\mathrm{Q}_{\mathrm{B}}$ (in the $\mathrm{Q}_{\mathrm{B}}{ }^{-}$state) in the WT RC more easily accommodates L212Glu that is fully protonated (49). Indeed, M246Glu is situated at the symmetry-related position of L212Glu. The relative position of $\mathrm{Q}_{\mathrm{A}}$ with regard to $\mathrm{M} 246 \mathrm{Glu}$ is similar to $\mathrm{Q}_{\mathrm{B}}$ in its proximal position relative to $\mathrm{L} 212 \mathrm{Glu}$. It is therefore interesting that $\mathrm{Q}_{\mathrm{A}}{ }^{-}$is less stable (progressive unbinding upon increasing $\mathrm{pH}$ ) as M246Glu deprotonates at high $\mathrm{pH}$ similar to $\mathrm{Q}_{\mathrm{B}}{ }^{-}$ when L212Glu gets ionized at similar $\mathrm{pH}$ values. This underlines the structural-functional analogy between events occurring at both quinone sites.

Proton uptake data (Figs. 4 and 5) show the same amplitudes for the M246Ala $\rightarrow$ Glu mutant and the WT RC at $\mathrm{pH}$ 10. This may seem to contradict the statement that M246Glu partly titrates at high $\mathrm{pH}$. Indeed, in that case, higher $\mathrm{H}^{+}$/ $\mathrm{Q}_{\mathrm{A}}{ }^{-}$and $\mathrm{H}^{+} / \mathrm{P}^{+} \mathrm{Q}_{\mathrm{A}}^{-}$values would have been expected at high $\mathrm{pH}$ in the mutant compared to the WT. It is in fact possible that the charge that exists on M246Glu at high $\mathrm{pH}$ (and detected in the charge recombination data) is buffered by an internal pool of protons, which, therefore, is not associated, at the same $\mathrm{pH}$, with concomitant proton uptake from outside the protein and detected by the dyes. This available internal reservoir of protons may be delocalized over the $\mathrm{Q}_{\mathrm{A}}-\mathrm{Q}_{\mathrm{B}}$ region. The high $\mathrm{pH}$ region (above $\mathrm{pH}$ 8.0) may be a signature of this proton pool, which may be common for the $Q_{A}$ and $Q_{B}$ regions of the protein. Such a reservoir, whose role could be to buffer the total response of the protein, may involve mobile and structured networks or clusters of water molecules, as we have recently suggested (50). This highlights the likely functional connections between the two quinone sites of the RC protein, as suggested previously $(11,16,18,21,38,40)$.

Increase of the $P^{+}$proton release in the M247Ala $\rightarrow$ Asp. The observed proton uptake is influenced by charges that are present in the RC molecule, which include $\mathrm{P}^{+}, \mathrm{Q}_{\mathrm{A}}^{-}$and the ionized residues of the complex. As shown in Fig. 6, the $\mathrm{pH}$-dependence curves for the apparent proton release $\left(\mathrm{H}^{+} /\right.$ $\mathrm{P}^{+}$) because of the formation of $\mathrm{P}^{+}$are nearly superimposable for the WT and the M246Ala $\rightarrow$ Glu mutant RC but differ significantly from that of the M247Ala $\rightarrow$ Asp mutant $\mathrm{RC}$. This result shows that the apparent proton release by $\mathrm{P}^{+}$, derived by a simple subtraction of the $\mathrm{H}^{+} / \mathrm{PQ}_{\mathrm{A}}^{-}$proton uptake curve from the $\mathrm{H}^{+} / \mathrm{P}^{+} \mathrm{Q}_{\mathrm{A}}{ }^{-}$curve, is affected by the M247Ala $\rightarrow$ Asp $Q_{A}$-site mutation. This observation that the difference between the two curves is not a constant- that it is dependent on mutation-suggests the existence of an interaction in the native $\mathrm{RC}$ between $\mathrm{P}^{+}$and $\mathrm{Q}_{\mathrm{A}}{ }^{-}$and the protein environment surrounding them. The M247Ala $\rightarrow$ Asp mutation reveals this interaction in the $\mathrm{pH}$ range that we monitor.

Should the interaction producing the observed effect, i.e. increased proton release by the $\mathrm{P}$ environment, in the M247Ala $\rightarrow$ Asp mutant be electrostatic, it would be higher than each two $\mathrm{pH}$ units (in $\Delta \mathrm{p} K$ units) in order to reveal groups that are not observed in the WT or in the M246Ala $\rightarrow$ Glu mutant. This is quite unlikely. We rather favor the hypothesis that the additional proton release observed in M247Ala $\rightarrow$ Asp mutant arises from a conformational modification of the protein, triggered by the $\mathrm{P}^{+}$formation and leading to a change in the exposure to the bulk phase of protonatable groups or internal water molecules (or both) in the $\mathrm{P}^{+}$surrounding. This has been reported for the WT (25) and could be amplified in the M247Ala $\rightarrow$ Asp mutant. This is consistent with recent work carried out with chromatophores of $R$. capsulatus, where notable interactions between the donor and acceptor sides of the RC complex have been demonstrated to exist and lead to conformational destabilization of the $\mathrm{P}^{+} \mathrm{Q}_{\mathrm{A}}{ }^{-}$state (22).

\section{CONCLUSIONS}

The more we know about the functional behavior of the RC protein, the more we are forced to interpret our experimental and theoretical data with the concept that static and dynamic interactions are delocalized over extended regions of the protein. The example given here of the "dialogue", between $\mathrm{P}^{+}$ and $\mathrm{Q}_{\mathrm{A}}^{-}$through the protein milieu reflects the fact that the protein is a complex unit. One main challenge in the future will be to understand the observed or calculated phenomena in the whole protein within the frame of their spatial and temporal interdependence.

Acknowledgements-We thank Dr. Laura Baciou and Jerôme Lavergne for helpful discussions during this work. This work was supported by the Human Frontier of Science Organization Grant RG 329/95 M, the Balaton Collaborative Research Grant (00834VL) and the CNRS. M.S. and D.K.H. were supported by the U.S. Department 
of Energy, Office of Biological and Environmental Research under contract W-31-109-ENG-38.

\section{REFERENCES}

1. Allen, J. P., G. Feher, T. O. Yeates, H. Komiya and D. C. Rees (1987) Structure of the reaction center from Rhodobacter sphaeroides R-26: the cofactors. Proc. Natl. Acad. Sci. USA 84, 5730.

2. El-Kabbani, O., C.-H. Chang, D. M. Tiede, J. Norris and M. Schiffer (1991) Comparison of reaction centers from Rhodobacter sphaeroides and Rhodopseudomonas viridis: overall architecture and protein-pigment interactions. Biochemistry 30, 5361.

3. Ermler, U., G. Fritzsch, S. K. Buchanan and H. Michel (1994) Structure of the photosynthetic reaction centre from Rhodobacter sphaeroides at $2.65 \AA$ resolution: cofactors and protein-cofactor interactions. Structure 2, 925.

4. Stowell, M. H., T. M. McPhillips, D. C. Rees, S. M. Soltis, E. Abresch and G. Feher (1997) Light-induced structural changes in photosynthetic reaction center: implications for mechanism of electron-proton transfer. Science 276, 812.

5. Maróti, P. and C. A. Wraight (1997) Kinetics of $\mathrm{H}^{+}$ion binding by the $\mathrm{P}+\mathrm{QA}-$ state of bacterial photosynthetic reaction centers: rate limitation within the protein. Biophys. J. 73, 367.

6. Miksovska, J., P. Maróti, J. Tandori, M. Schiffer, D. K. Hanson and P. Sebban (1996) Distant electrostatic interactions modulate the free energy level of $\mathrm{Q}_{\mathrm{A}}{ }^{-}$in the photosynthetic reaction center. Biochemistry 35, 15411.

7. Tiede, D. M., J. Vazquez, J. Cordova and P. A. Marone (1996) Time-resolved electrochromism associated with the formation of quinone anions in the Rhodobacter sphaeroides $\mathrm{R} 26$ reaction center. Biochemistry 35, 10763.

8. Brzezinski, P., M. Y. Okamura and G. Feher (1992) Structural changes following the formation of $\mathrm{D}^{+} \mathrm{Q}_{\mathrm{A}}^{-}$in bacterial reaction centers: measurement of light-induced electrogenic events in RCs incorporated in a phospholipid bilayer. In The Photosynthetic Bacterial Reaction Center II, Vol. m (Edited by J. B. A. Vermeglio), pp. 321. Plenum Press, New York.

9. Kleinfeld, D., M. Y. Okamura and G. Feher (1984) Electrontransfer kinetics in photosynthetic reaction centers cooled to cryogenic temperatures in the charge-separated state: evidence for light-induced structural changes. Biochemistry 23, 5780 .

10. Tiede, D. M. and D. K. Hanson (1992) Protein relaxation following quinone reduction in Rhodobacter capsulatus: detection of likely protonation-linked optical absorbance changes of the chromatophores. In The Photosynthetic Bacterial Reaction Center II, Vol. m (Edited by J. B. A. Vermeglio), pp. 343. Plenum Press, New York.

11. Miksovska, J., M. Schiffer, D. K. Hanson and P. Sebban (1999) Proton uptake by bacterial reaction centers: the protein complex responds in a similar manner to the reduction of either quinone acceptor. Proc. Natl. Acad. Sci. USA 96, 14348.

12. Miksovska, J., P. Maróti, M. Schiffer, D. K. Hanson and P. Sebban (1995) Electrostatic interaction between L212Glu and $\mathrm{Q}_{\mathrm{A}}^{-}$in reaction centers. In Photosynthesis: From Light to Biosphere, Vol. 1 (Edited by P. Mathis), pp. 467. Kluwer Academic Publishers, Dordrecht, The Netherlands.

13. McPherson, P. H., M. Schönfeld, M. L. Paddock, M. Y. Okamura and G. Feher (1994) Protonation and free energy changes associated with formation of $\mathrm{Q}_{\mathrm{B}} \mathrm{H}_{2}$ in native and Glu-L212 $\rightarrow$ Gln mutant reaction centers from Rhodobacter sphaeroides. Biochemistry 33, 1181.

14. Li, J., D. Gilroy, D. M. Tiede and M. R. Gunner (1998) Kinetic phases in the electron transfer from $\mathrm{P}^{+} \mathrm{Q}_{\mathrm{A}}{ }^{-} \mathrm{Q}_{\mathrm{B}}$ to $\mathrm{P}^{+} \mathrm{Q}_{\mathrm{A}} \mathrm{Q}_{\mathrm{B}}{ }^{-}$and the associated processes in Rhodobacter sphaeroides $\mathrm{R}-26$ reaction centers. Biochemistry 37, 2818.

15. Li, J., E. Takahashi and M. R. Gunner (2000) $-\Delta G_{\text {ab }}$ and $\mathrm{pH}$ dependence of the electron transfer from $\mathrm{P}^{+} \mathrm{Q}_{\mathrm{A}}{ }^{-} \mathrm{Q}_{\mathrm{B}}$ to $\mathrm{P}^{+} \mathrm{Q}_{\mathrm{A}} \mathrm{Q}_{\mathrm{B}}$ in Rhodobacter sphaeroides reaction centers. Biochemistry 39, 7445 .

16. Wraight, C. A. (1998) Functional Linkage Between the $Q_{A}$ and $Q_{B}$ sites of Photosynthetic Reaction Centers, Vol. 2 (Edited by G. Garak), pp. 693. Kluwer Academic, Budapest.

17. Wraight, C. A. and R. R. Stein (1980) Redox equilibrium in the acceptor quinone complex of isolated reaction centers and the mode of action of $o$-phenanthroline. FEBS Lett. 113, 73.

18. Dutton, P. L., J. S. Leigh and C. A. Wraight (1973) Direct measurement of the midpoint potential of the primary electron acceptor in Rhodopseudomonas sphaeroidesin situ and in the isolated state: some relationships with $\mathrm{pH}$ and $o$-phenanthroline. FEBS Lett. 36, 169.

19. Prince, R. C. and P. L. Dutton (1978) Protonation and the reducing potential of the primary electron acceptor. In The Photosynthetic Bacteria, (Edited by R. K. Clayton and W. R. Sistrom), pp. 439. Plenum Press, New York.

20. Gunner, M. R., D. M. Tiede, R. C. Prince and P. L. Dutton (1982) In Functions of Quinones in Energy Conserving Systems, (Edited by B. L. Trumpower), pp. 265. Academic Press, New York.

21. Baciou, L. and P. Sebban (1995) Heterogeneity of the quinone electron acceptor system in bacterial reaction centers. Photochem. Photobiol. 62, 271.

22. Ginet, N. and J. Lavergne (2000) Interactions between the donor and acceptor sides in bacterial reaction centers. Biochemistry 39 , 16252 .

23. McPherson, P. H., M. Y. Okamura and G. Feher (1988) Lightinduced proton uptake by photosynthetic reaction centers from Rhodobacter sphaeroides R-26. I. Protonation of the one-electron states $\mathrm{D}^{+} \mathrm{Q}_{\mathrm{A}}^{-}, \mathrm{DQ}_{\mathrm{A}}$, and $\mathrm{DQ}_{\mathrm{A}} \mathrm{Q}_{\mathrm{B}}{ }^{-}$. Biochim. Biophys. Acta 934, 348.

24. Maroti, P. and C. A. Wraight (1988) Flash-induced $\mathrm{H}^{+}$binding by bacterial photosynthetic reaction centers: influences of the redox states of the acceptor quinones and primary donor. Biochim. Biophys. Acta 934, 329.

25. Kalman, L. and P. Maroti (1997) Conformation-activated protonation in reaction centers of the photosynthetic bacterium Rhodobacter sphaeroides. Biochemistry 36, 15269.

26. Hanson, D. K., D. M. Tiede, S. L. Nance, C. H. Chang and M. Schiffer (1993) Site-specific and compensatory mutations imply unexpected pathways for proton delivery to the $\mathrm{Q}_{\mathrm{B}}$ binding site of the photosynthetic reaction center. Proc. Natl. Acad. Sci. USA 90, 8929.

27. Hanson, D. K., L. Baciou, D. M. Tiede, S. L. Nance, M. Schiffer and P. Sebban (1992) In bacterial reaction centers protons can diffuse to the secondary quinone by alternative pathways. Biochim. Biophys. Acta 1102, 260.

28. Schiffer, M., C.-K. Chan, C.-H. Chang, T. J. DiMagno, G. R. Fleming, S. L. Nance, J. R. Norris, S. Snyder, M. C. Thurnauer, D. M. Tiede and D. K. Hanson (1992) Study of reaction center function by analysis of the effects of site-specific and compensatory mutations. In The Photosynthetic Bacterial Reaction Center II, NATO ASI Series, (Edited by J. B. A. Vermeglio), pp. 251. Plenum Press, London.

29. Laible, P. D., Y. Zhang, J. Norris, S. W. Snyder, C. Ainsworth, S. Greenfield, M. R. Wasielewski, P. Parot, B. Schoepp, M. Schiffer, D. K. Hanson and M. C. Thurnauer (1997) Spectroscopic characterization of quinone-site mutants of the bacterial photosynthetic reaction center. Photosynth. Res. 52, 93.

30. Baciou, L., E. J. Bylina and P. Sebban (1993) Study of wild type and genetically modified reaction centers from Rhodobacter capsulatus: structural comparison with Rhodopseudomonas viridis and Rhodobacter sphaeroides. Biophys. J. 65, 652.

31. Miksovska, J., M. Valerio-Lepiniec, M. Schiffer, D. K. Hanson and P. Sebban (1998) In bacterial reaction centers, a key residue suppresses mutational blockage of two different proton transfer steps. Biochemistry 37, 2077.

32. Maróti, P., D. K. Hanson, L. Baciou, M. Schiffer and P. Sebban (1994) Proton conduction within the reaction centers of Rhodobacter capsulatus: the electrostatic role of the protein. Proc. Natl. Acad. Sci. USA 91, 5617.

33. Wraight, C. A. (1979) Electron acceptors of bacterial photosynthetic reaction centers. II. $\mathrm{H}^{+}$binding coupled to secondary electron transfer in the quinone acceptor complex. Biochim. Biophys. Acta 548, 309.

34. Labahn, A., M. L. Paddock, P. H. McPherson, M. Y. Okamura and G. Feher (1994) Direct charge recombination from $\mathrm{D}^{+} \mathrm{Q}_{\mathrm{A}}{ }^{-} \mathrm{Q}_{\mathrm{B}}{ }^{-}$to $\mathrm{D}^{+} \mathrm{Q}_{\mathrm{A}} \mathrm{Q}_{\mathrm{B}}$ in bacterial reaction centers from $R b$. sphaeroides. J. Phys. Chem. 98, 3417. 


\section{Julia Tandori et al.}

35. Graige, M. S., G. Feher and M. Y. Okamura (1998) Conformational gating of the electron transfer reaction $\mathrm{Q}_{\mathrm{A}}{ }^{-} \mathrm{Q}_{\mathrm{B}} \rightarrow$ $\mathrm{Q}_{\mathrm{A}} \mathrm{Q}_{\mathrm{B}}{ }^{-}$in bacterial reaction centers of Rhodobacter sphaeroides determined by a driving force assay. Proc. Natl. Acad. Sci. USA 95, 11679.

36. Sebban, P., P. Maróti and D. K. Hanson (1995) Electron and proton transfer to the quinones in bacterial photosynthetic reaction centers: insight from combined approaches of molecular genetics and biophysics. Biochimie 77, 677.

37. Maróti, P., D. K. Hanson, M. Schiffer and P. Sebban (1995) Long-range electrostatic interaction in the bacterial photosynthetic reaction centre [letter]. Nat. Struct. Biol. 2, 1057.

38. Alexov, E. G. and M. R. Gunner (1999) Calculated protein and proton motions coupled to electron transfer: electron transfer from $\mathrm{Q}_{\mathrm{A}}{ }^{-}$to $\mathrm{Q}_{\mathrm{B}}$ in bacterial photosynthetic reaction centers. Biochemistry 38, 8253.

39. Rabenstein, B., G. M. Ullmann and E. W. Knapp (1998) Energetics of electron-transfer and protonation reactions of the quinones in the photosynthetic reaction center of Rhodopseudomonas viridis. Biochemistry 37, 2488.

40. Rabenstein, B., G. M. Ullmann and E. W. Knapp (2000) Electron transfer between the quinones in the photosynthetic reaction center and its coupling to conformational changes. Biochemistry 39, 10487.

41. Miksovska, J., L. Kálmán, M. Schiffer, P. Maróti, P. Sebban and D. K. Hanson (1997) In bacterial reaction centers rapid delivery of the second proton to $\mathrm{Q}_{\mathrm{B}}$ can be achieved in the absence of L212Glu. Biochemistry 36, 12216.

42. Brzezinski, P., M. L. Paddock, M. Y. Okamura and G. Feher (1997) Light-induced electrogenic events associated with proton uptake upon forming $\mathrm{Q}_{\mathrm{B}}{ }^{-}$in bacterial wild-type and mutant reaction centers. Biochim. Biophys. Acta 1321, 149.

43. Nabedryk, E., J. Breton, H. M. Joshi and D. K. Hanson (2000)
Fourier transform infrared evidence of proton uptake by glutamate L212 upon reduction of the secondary quinone $\mathrm{Q}_{\mathrm{B}}$ in the photosynthetic reaction center from Rhodobacter capsulatus. Biochemistry 39, 14654.

44. Lancaster, C. R., H. Michel, B. Honig and M. R. Gunner (1996) Calculated coupling of electron and proton transfer in the photosynthetic reaction center of Rhodopseudomonas viridis. Biophys. J. 70, 2469.

45. Lancaster, C. R. and H. Michel (1997) The coupling of lightinduced electron transfer and proton uptake as derived from crystal structures of reaction centres from Rhodopseudomonas viridis modified at the binding site of the secondary quinone, $\mathrm{Q}_{\mathrm{B}}$. Structure 5, 1339.

46. Beroza, P., D. R. Fredkin, M. Y. Okamura and G. Feher (1995) Electrostatic calculations of amino acid titration and electron transfer, $\mathrm{Q}_{\mathrm{A}}{ }^{-} \mathrm{Q}_{\mathrm{B}} \rightarrow \mathrm{Q}_{\mathrm{A}} \mathrm{Q}_{\mathrm{B}}{ }^{-}$, in the reaction center. Biophys. $J$. 68, 2233.

47. Alexov, E., J. Miksovska, L. Baciou, M. Schiffer, D. K. Hanson, P. Sebban and M. R. Gunner (2000) Modeling the effects of mutations on the free energy of the first electron transfer from $\mathrm{Q}_{\mathrm{A}}{ }^{-}$to $\mathrm{Q}_{\mathrm{B}}$ in photosynthetic reaction centers. Biochemistry 39, 5940 .

48. Ullmann, G. M. and E. W. Knapp (1999) Electrostatic models for computing protonation and redox equilibria in proteins. Eur. J. Biochem. 28, 533.

49. Grafton, A. K. and R. A. Wheeler (1999) Amino acid protonation states determine binding sites of the secondary ubiquinone and its anion in the Rhodobacter sphaeroides photosynthetic reaction center. J. Phys. Chem. B 103, 5380.

50. Tandori, J., L. Baciou, E. Alexov, P. Maróti, M. Schiffer, D. K. Hanson and P. Sebban (2002) Revealing the involvement of extended hydrogen-bond networks in the cooperative function between distant sites in bacterial centers. J. Biol. Chem. (In press) 